\section{Mariola Jakubowicz}

Instytut Slawistyki PAN w Warszawie

mjakub7@interia.pl
Data przesłania tekstu do redakcji: 24.11.2014

Data przyjęcia tekstu do druku: 05.01.2015

\title{
Co się ukrywa za nazwami emocji?
}

Abstract: Jakubowicz Mariola, Co się ukrywa za nazwami emocji? (What Meaning Lies Behind the Names of Emotions?). "Poznańskie Studia Slawistyczne" 9. Poznań 2015. Publishing House of the Poznań Society for the Advancement of the Arts and Sciences, pp. 439-448. ISSN 2084-3011.

The article is devoted to the semantic motivations of the names of feelings. Its aim is to prove that when one researches semantic motivations one discovers the original associations connected with referents, in this case, feelings. In order to present the problem in an accessible way the most legible of the names were chosen for the analysis - especially those which acquired the meaning of a feeling by way of metaphor. The names whose structure is clear but which lost their legibility due to lexicalisation were also considered.

KeYwords: emotions; feelings; metaphor; semantic motivation; etymology; development of meaning

Przedmiotem niniejszego artykułu jest analiza wybranych polskich nazw emocji i ich innojęzycznych odpowiedników opartych na tych samych modelach motywacyjnych. Kluczowym pojęciem w badaniach jest motywacja semantyczna, czyli semantyka wyrazu fundującego nazwę interesującą badacza. Mówiąc o emocjach, warto zastanowić się nad skojarzeniami, które są z nimi zwykle wiązane. Asocjacje te można badać na podstawie różnych płaszczyzn językowych, np. poprzez śledzenie odpowiednich wątków w literaturze czy też przez analizę sfrazeologizowanych jednostek językowych zawierających jako komponent nazwę uczucia albo pośrednio mówiących o uczuciach. Można też uciec się do badań etymologicznych samych nazw emocji kryjących w sobie informacje dotyczące motywacji semantycznej. Badania etymologiczne opierają się przede wszystkim na odpowiedniości form, nie należy jednak lekceważyć semantyki. Analizy rozwoju znaczenia mogą uwiarygodnić albo obalić hipotezę etymologiczną. Szczególnie obiecujące są badania całych pól semantycznych, pomocne nie tylko dla etymologów, ale również dla badaczy światów kryjących się za słowami. Podobnie jak wszystkie inne desygnaty, 
również nazwy uczuć zdradzają skojarzenia obecne w momencie swego powstania. W niniejszym artykule chcę się zająć tymi nazwami emocji, które - przy odrobinie wysiłku - może rozszyfrować osoba znająca dany język. Najprostsze i niewymagające specjalnego aparatu badawczego jest śledzenie uczuć sygnalizowanych za pomocą metafor. Określanie emocji nazwami przenośnymi, zachowującymi jednocześnie znaczenie podstawowe, jest zjawiskiem wręcz seryjnym. Ten poziom badań jest dostępny nawet bez korzystania ze słowników etymologicznych. Ich podstawą jest porównywanie znaczeń podstawowych i metaforycznych w słownikach tłumaczeniowych i objaśniających. Z reguły te pierwsze określają zjawiska materialne (bardzo często związane z fizjologią), natomiast drugie odnoszą się do życia uczuciowego. Aby pokazać prawidłowości działające przy nazewnictwie emocji, poza nazwami polskimi przytaczam też przykłady pochodzące z innych języków używanych w Europie. Wiele z nich pochodzi z języka greckiego, cennego dla badań ze względu na wielowiekową kulturę piśmienną. Porównanie znaczeń słów starogreckich zawartych w czterotomowym słowniku grecko-polskim (Abramowiczówna 1958-1965) ze znaczeniami ich nowogreckich „potomków” pokazuje, że niejednokrotnie znaczenia emotywne - początkowo tylko metaforyczne usamodzielniły się i we współczesnej grece całkowicie wyparły znaczenia

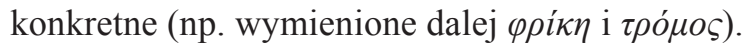

Zacznę od uczucia strachu, który jest jedną z podstawowych, najbardziej pierwotnych emocji, charakterystyczną zarówno dla ludzi, jak i zwierząt. Naturalne więc wydaje się, że źródłem jego nazw będą przede wszystkim odruchy fizjologiczne występujące w momencie pojawienia się strachu. Reakcją najczęściej pojawiającą się w funkcji figuratywnej nazwy strachu jest drżenie. Przykłady z języków słowiańskich to serbskie i chorwackie trêsti, słoweńskie trepèt, bułgarskie mpènem, rosyjskie mpénem. Wszystkie wywodzą się od prasłowiańskiego *trepetb - derywatu wstecznego od *trepetati 'trząść się, drżeć, dygotać; trzepotać'. Znaczenie leksemu 'strach' w żadnym z języków słowiańskich nie występuje samodzielnie, lecz jest notowane jako figuratywne obok podstawowego 'drżenie'. Na etapie znaczenia przenośnego zatrzymał się także rozwój semantyczny innych leksemów oznaczających drżenie: cf. polskie drżeć i trząść się. Przykładów nie brak też w innych językach. Niemieckie Schauder 'dreszcz, ciarki; drżenie' - derywat wsteczny od schaudern 
'drżeć, odczuwać dreszcze; trząść się (ze strachu lub zimna)’ przenośnie znaczy 'zgroza'. W języku nowogreckim strach jest określany wyrazami

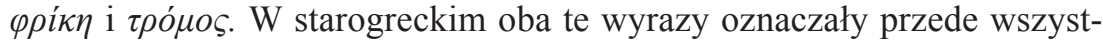
kim 'dreszcz, drżenie'.

Łacińskie horrere 'jeżyć się; drżeć, wzdrygać się’ jest podstawą rozpowszechnionego dziś internacjonalizmu horror. W łacinie wyraz ten obok podstawowego 'drżenie, dygotanie; drętwienie', znaczył 'groza, strach; obrzydzenie'. Ten sam obraz odnajdujemy w chorwackim i serbskim strépnja 'niepokój, obawa, lęk', który jest derywatem od strépjeti, strépiti - pierwotnie: 'drżeć; cierpnąć, drętwieć'. Warto zwrócić uwagę na zmniejszenie intensywności w stosunku do znaczenia motywującego, kojarzącego się z bardzo silnym uczuciem strachu. Z kolei chorwackie i serbskie zêpsti 'odczuwać chłód' przenośnie znaczy 'odczuwać strach'. Źródłem nazw strachu są również inne reakcje fizjologiczne, np. łacińskie pallor 'bladość', przenośnie oznacza 'lęk, strach'. Oddalając się na chwilę od strachu, zauważmy, że inne określenie koloru skóry livor 'siność' oznacza w języku łacińskim również 'zawiść'.

Nazwy kolejnej emocji - gniewu - mogą być wyrażone za pomocą metafory, mającej podłoże w funkcjonowaniu organizmu człowieka. I tak w języku starogreckim gniew mógł być wyrażony przez leksem $\theta v \mu o ́ \varsigma$ o podstawowym znaczeniu 'oddech'. Motywacja powstania użycia metaforycznego wydaje się jasna. Co prawda, w języku polskim to przede wszystkim podziw ,zapiera dech w piersiach”, ale z łatwością możemy podstawić na miejsce podziwu każde inne, byle silne, uczucie, np. właśnie gniew.

Innym źródłem motywacji były nazwy części ciała podejrzewane o związek z powstawaniem uczuć. W naszym kręgu kulturowym podstawowym organem wiązanym $z$ emocjami jest oczywiście serce. Nie łączy się ono jednak, jak w związkach frazeologicznych, z miłością, ale z gniewem. Polskie sierdzić się, rosyjskie сердиться i innosłowiańskie odpowiedniki odnoszą się właśnie do tego uczucia. U podstawy wymienionych czasowników słowiańskich stoi prasłowiański rekonstrukt *sbrdb (Boryś 2005: 522), będący także podstawą deminutywnego *sbrdbce, kontynuowanego w naszym języku przez serce. Podobnie jest w języku albańskim, w którym czasownik o znaczeniu 'gniewam się' - zemëroj jest derywatem od zemër - 'serce'. Nazwa gniewu może być także związana z inną 
częścią ciała, mianowicie z żołądkiem. W łacinie derywat od stomachus 'żołądek' - stomachari znaczył 'gniewać się, oburzać, irytować się, dąsać' (stąd polskie ,żołądkować się” - kalka z języka łacińskiego). Ciekawe, że sam stomachus 'żołądek' metaforycznie mógł oznaczać nie tylko 'gniew, rozdrażnienie, irytację', ale także nastroje i usposobienia diametralnie przeciwne: 'cierpliwość, wytrzymałość, skłonność do zgody' (Korpanty 2003: 769). Z kolei w angielskim 'zły nastrój, chandra, złość' może być wyrażony wyrazem spleen (pożyczka ze stgrec. $\sigma \pi \lambda \eta \dot{v}$ za pośrednictwem łac. splen) o podstawowym znaczeniu 'śledziona'. Ponieważ wiadomo, że w różnych kulturach różnie lokalizowane były uczucia, można się spodziewać, że nazwy emocji powstawały również w oparciu o nazwy niewymienionych tutaj części ciała.

Uczucie zbliżone do gniewu i złości jest określane mianem żółci. $\mathrm{W}$ języku polskim istnieje ono tylko jako składnik stałych połączeń wyrazowych, przede wszystkim: ,żółć mnie zalewa”. W języku starogreckim istniały nazwy synonimiczne $\chi 0 \lambda \eta$, $\chi o ́ \lambda o \varsigma$ przen. 'gniew, oburzenie, złość; zawiść, wstręt', z których pierwsza zachowała znaczenie pierwotne 'żółć', druga zaś $\chi o ́ \lambda o \varsigma$ stała się samodzielną nazwą emocji. Francuskie colère 'gniew' oraz włoskie collera, a także hiszpańskie i portugalskie cólera w tym samym znaczeniu, są kontynuantami łacińskiego cholera 'żółć; żółtaczka' wyrazu zapożyczonego z greki. Obok tej pożyczki istniał również rodzimy wyraz łaciński fel 'żółć', przen. 'irytacja; złość'. Takie same znaczenia pierwotne i wtórne mają również niemieckie Galle, niderlandzkie gal, szwedzkie galla i angielskie gall (pochodzące z jednego pragermańskiego źródła) oraz litewskie tulžís. Wszystkie te wyrazy - również polska żółć - wywodzą się ze wspólnego źródła praindoeuropejskiego, trudno jednak orzec, czy metaforyczne znaczenie ‘irytacja; złość’ można uznać za powstałe już w prajęzyku współcześnie z podstawowym, czy też zaczęło ono funkcjonować w starożytnej Grecji wskutek pojawienia się teorii „humorów" w medycynie antycznej, a w Europie rozpowszechniło się dopiero wraz z ekspansją kultury klasycznej.

Obok wydzielin organizmu podstawą nazw emocji mogły stać się także inne substancje. Francuskie venin 'jad; trucizna' i niemieckie Gift w tym samym znaczeniu to przenośnie 'złość, złośliwość', natomiast albańskie helm 'trucizna', znaczy także 'rozpacz'. Francuskie aigreur 'kwas', przen. 'rozgoryczenie; przykrość, uraza', podobnie angielska pożyczka z łaciny 
acrimony, która zresztą ma wspólne korzenie z wyrazem francuskim, a ich pierwotna motywacja wiąże się z ostrością.

Przejdźmy teraz do emocji bardziej złożonych, właściwych człowiekowi. Zarówno w języku polskim, jak i w innych funkcjonują nazwy oznaczające w warstwie podstawowej gorzki smak, w przenośnej zaś uczucie bliskie smutkowi, czasem - zawiedzionym oczekiwaniom. Przykłady można znaleźć we wszystkich grupach językowych, poczynając od polskiej goryczy. Jej odpowiedniki w innych językach to greckie $\pi \imath \kappa \rho i \alpha$, łacińskie amaritudo 'gorzki smak', francuskie amertume, włoskie amareggiamento, hiszpańskie amargor 'ts.' niemieckie Bitterkeit, niderlandzkie bitterheid, angielskie bitterness. Wszystkie wymienione nazwy znaczą zarówno 'gorzki smak', jak i - metaforycznie - 'rozgoryczenie, smutek, przykrość, uraza, żal'. Oczywiście mogą to być kalki językowe. Gdy spojrzymy do Konkordancji Biblijnej ${ }^{1}$ zobaczymy, że podejrzenie to w wypadku odpowiedników słowa gorycz jest wysoce uzasadnione.

Na bazie przenośnej podstawy wytworzyły się derywaty służące już tylko określeniu uczucia. Od gorycz powstał czasownik rozgoryczyć, dziś funkcjonujący tylko w formie imiesłowowej rozgoryczony i jako rzeczownik odsłowny rozgoryczenie. Jest to inny sposób tworzenia nazw emocji, do którego powrócę jeszcze w dalszej części artykułu.

Nazwy żalu często są tożsame z nazwami bólu. W językach słowiańskich kontynuanty psł. *bolb i bolestb metaforycznie mają znaczenie 'żal'. Nie inaczej jest w innych europejskich językach. Niemieckie Schmerz, litewskie skãusmas, włoskie dolore, rumuńskie durere oraz greckie $\lambda v ́ \pi \eta$, a także inne, tu niewymienione, oznaczają zarówno cierpienie fizyczne, jak i psychiczne, czyli żal. Równie często znaczenie metaforyczne otrzymują konkretne nazwy bólu, np. litewskie gèlà 'darcie, łamanie', przen. 'gorycz, żal', a także - w tym samym języku - maudulys 'ćmienie, strzykanie', przen. 'żal; tęsknota', czy portugalskie mágoa 'stłuczenie, siniec', przen. 'żal'. Interesujące jest też starogreckie $\kappa \alpha \tilde{\nu} \mu \alpha$ 'skwar, upał, gorąco', które w języku nowogreckim zmieniło znaczenie na 'żal'. Ogniwem pośrednim niewątpliwie musiało być nieprzyjemne czy nawet bolesne uczucie pieczenia. Szczególną grupę tworzą te nazwy, które łączą się z naciskiem, uciskaniem, ciężarem, np. hiszpańskie pesar 'ważyć, ciążyć', przen. 'sprawiać

\footnotetext{
${ }^{1}<$ http://biblia.apologetyka.com/search>, 30.10.2014.
} 
ból', a także 'sprawiać przykrość'. Z kolei czasownik $\theta \lambda i \beta \varepsilon \imath v$ w starogreckim znaczył 'cisnąć, ocierać, ugniatać; ściskać, ścieśniać', w nowogreckim 'ściskać', 'martwić, trapić'. W języku czeskim stísněnost przenośnie znaczy 'przygnębienie' (inne znaczenie przenośne to 'bieda, niedostatek'), natomiast podstawowe znaczenie to 'ciasnota, ograniczoność'.

Kontynuanty ogólnosłowiańskiego wyrazu prasłowiańskiego pochodzenia *moka oznaczają zarówno zadawanie, jak i odczuwanie cierpienia fizycznego, a figuratywnie w prawie wszystkich językach słowiańskich można nimi nazwać cierpienie duchowe, żal i smutek. Motywacją znaczenia 'męczyć, zadawać cierpienie' jest 'gnieść, miażdżyć; rozdrabniać', co wiąże te nazwy z wymienionymi niżej griža czy zgryzota. Z kontynuantami *moka można porównać też włoskie tormento 'męka', przen. 'męka duchowa; żal' lub też włoskie, hiszpańskie i portugalskie pena 'kara', 'męka; cierpienie; żal'.

Kolejna motywacja nazw smutku łączy się z różnie wyrażanym ruchem w dół, co jest zgodne z jednym ze schematów kognitywnych „w dół - to źle". Przykładem mogą być dwa znaczenia internacjonalizmu w języku polskim mającego formę depresja. Ruch w dół może być różnie wyrażany, poczynając od skojarzeń z ciężarem, jak w wymienionym wyżej hiszpańskim pesar, kończąc na środkach gramatycznych, jak np. w wypadku holenderskego nedstämma 'być w złym nastroju' złożonego z ned'w dół' i stämma 'nastrajać'. Obraz ruchu w dół jest też obecny w potocznym określeniu być zdołowanym.

Wymienione powyżej podstawy przenośnych nazw żalu, smutku i przygnębienia tworzą kontinuum. Powodem użycia starogreckiego $\theta \lambda i \beta \varepsilon \imath v$ 'cisnąć, ocierać, ugniatać; ściskać' dla nowogreckiego 'martwić, trapić’ może być zarówno skojarzenie z bólem, jak i z ograniczeniem przestrzeni. Motyw ruchu w dół może mieć podstawy w uniwersalnych schematach wyobrażeniowych, ale mógł powstać także na bazie skojarzenia z działaniem ciężaru, przyciskaniem, ograniczaniem.

Sposobem nazywania uczuć jest też tworzenie derywatów od wyrazów kojarzonych z tymi emocjami, jak zostało to przedstawione na przykładzie nazw rozgoryczenie czy rozsierdzić się. W tym przypadku, podobnie jak przy omówionych już przenośnych nazwach emocji, rozpoznanie ich pochodzenia jest stosunkowo łatwe. Stosunkowo, ponieważ na przeszkodzie staje skłonność do traktowania leksemów jako jednostek niepodzielnych. 
Wiele przykładów można znaleźć w języku polskim. Czasownik martwić sie jest niewątpliwie derywatem od przymiotnika martwy. Ścieżkę rozwoju znaczenia tego wyrazu można odnaleźć w znanym z terminologii kościelnej czasowniku umartwiać się. Umartwianie ciała przez posty, samobiczowanie i inne praktyki ascetyczne miało spowodować zbliżenie się do męki i śmierci Chrystusa - symboliczne czynienie z siebie martwego. Czasownik truchleć - dziś kojarzony raczej ze strachem - w staropolskim będący synonimem martwić się, z wyraźną wówczas podstawą derywacyjną truchty - 'osłabiony, bez sił', popiera możliwość takiego rozwoju semantycznego.

Innymi przykładami są nazwy uczuć będące derywatami od czasownika razić, dawniej powszechnego synonimu do bić, dziś zarezerwowanego raczej do określonych połączeń, np. razić o słońcu, porazić o prądzie. Nazwa emocji oparta na przedrostkowym przerazić - przerażenie początkowo mogła oznaczać każde silne uczucie, dopiero potem została ograniczona do silnego strachu. Przykłady użyć w innych znaczeniach emotywnych podaje Danuta Buttler (1978: 99). Z kolei od czasownika z prefiksem od- : odrazić, pochodzi odraza, nazwa emocji zbliżonej do wstrętu. Motywacją obu wymienionych tu nazw była siła uczucia. Na modelu analogicznym do słowa odraza, oparta jest nazwa wstręt. Trudniej ją rozszyfrować niż poprzednią, ponieważ jedna z jej części składowych, przedrostek wyz-/wez-/ $w z$ - przestał być produktywny $\mathrm{w}$ języku polskim. Jest on obecny $\mathrm{w}$ serii wyrazów, np. „wschód w opozycji do zachód czy wzniesienie. Jedną z funkcji owego przedrostka była funkcja ablatywna (typowa dla przedrostka 'od-). Złożony niegdyś wyraz wstręt można podzielić na prefiks ws- i rdzenne -tręt (cf. też natręt). Podstawa wstrącić oboczne do wstręcić (się) - 'odepchnąć, usunąć; wyrazić sprzeciw' jest poświadczona źródłami staropolskimi (Buttler 1978: 94). Jak wspomniano, nazwy emocji często powstają seryjnie: wstręt i odraza mają paralele w różnych językach. Łacińskie repulsio, deverbativum od repellere 'odpychać, odrzucać', ma znaczenie konkretne, natomiast pochodzące od niego wyrazy w językach romańskich wytworzyły znaczenie przenośne 'odraza, wstręt; niechęć', $\mathrm{np}$. francuskie répulsion, włoskie ripulsione ${ }^{2}$. Z kolei włoskie ributtante 'wstrętny' było pierwotnie imiesłowem od (ri)buttare 'rzucać, ciskać'.

\footnotetext{
${ }^{2}$ Nie zajmuję się tu charakterem związku wyrazów romańskich z łacińskimi. Jak w wielu innych wypadkach chodzi o pożyczkę z języka-matki, nie o regularny kontynuant.
} 
Kolejna interesująca nazwa - zachwyt od być zachwyconym - formalnie nie różni się zupełnie od być pochwyconym i oznacza 'znalezienie się we władzy tego, co zachwyciło’. Zaskoczenie jest również bardzo obrazową, a niekoniecznie uświadamianą przez mówiących, formą nazwania uczucia. Być może do dziś czytelna jest motywacja nazw oczarowanie i rozczarowanie. Jeśli tak się dzieje, jest to zapewne spowodowane opozycją pary przedrostkowej, która uwidacznia ich budowę.

Jak widać, znaczna część czytelnych nazw emocji powstałych na bazie czasowników jest oparta na imiesłowie przymiotnikowym biernym. Nie jest to jednak regułą. Rzeczownikiem odpowiadającym formie werbalnej być skruszonym nie jest skruszenie, ale skrucha. Zgryzota - jest rzeczownikiem z sufiksem -ota pochodzącym od prefigowanego czasownika z-gryźć. W językach południowosłowiańskich na bazie tegoż czasownika powstał rzeczownik griža 'troska, smutek'.

$\mathrm{Na}$ koniec pozostawiłam wyrazy, których związek z podstawą motywacyjną nie jest tak widoczny, jednak możliwy do objaśnienia bez wychodzenia poza język polski. Pochodzenie przymiotnika smutny jest zrozumiałe, jeżeli mamy świadomość istnienia jego wariantu smętny. W formie smętny nietrudno dopatrzeć się związku z przymiotnikiem mętny. Bezpośrednią podstawą przymiotnika smętny jest prefigowany czasownik smęcić. Znacznie powszechniejsza dziś forma smutny jest uważana bądź to za bohemizm (Basaj, Siatkowski 2006), bądź to za pozostałość prasłowiańskiej oboczności $q$ do $u$ (Sławski 1939-1947: 278). Paralelę semantyczną znajdziemy w angielskim wyrazie gloom 'ciemność, mrok', przen. 'przygnębienie, depresja'.

Czasownik lękać się oznaczający 'strach przed czymś, co może istnieć realnie, ale może też być dopiero przewidywane', pochodzi z języka prasłowiańskiego i kiedyś znaczył 'zginać się', co łatwo zinterpretować jako pochylenie się w celu ukrycia się przed zagrożeniem. Na pierwotne znaczenie czasownika wskazują takie polskie rzeczowniki, jak łęk, pałąk, a także $\iota u k$, choć w tym ostatnim, ze względu na wokalizm $u$, należy się dopatrywać raczej pożyczki z języka czeskiego. Wszystkie wymienione wyrazy odnoszą się do przedmiotów o wygiętym kształcie. Nazwy reakcji na strach również mają paralele w innych językach. Można tu wymienić

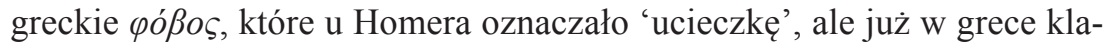
sycznej 'strach'. 
W artykule skoncentrowałam się na nazwach przenośnych. Moim celem było przekrojowe przedstawienie najbardziej charakterystycznych motywacji nazw emocji. Szczególnie rzucający się w oczy związek stanu fizycznego z psychicznym jest widoczny także w rozpatrywanych nazwach derywowanych. Przykłady przedstawione w tekście mogą stanowić podstawę planowanego korpusu motywacji semantycznych nazw emocji. Korpus taki ułatwi badaczom ocenę od strony semantycznej hipotez dotyczących innych nazw emocji, ponieważ etymologia wielu spośród nich nie jest jednoznacznie ustalona ${ }^{3}$.

W moim artykule nieprzypadkowo znalazły się wyrazy z najróżniejszych języków europejskich. Chciałam za ich pomocą wykazać powszechność schematów tworzenia nazw emocji. Ta powszechność ma przynajmniej dwa powody. Po pierwsze, przedstawione przykłady pochodzą z jednego kręgu kulturowego i jest to jedną z przyczyn zgodności motywacji w różnych językach. Po drugie, podłoże motywacji nazw uczuć jest fizjologiczne, do pewnego stopnia warunkujące skojarzenia (np. skojarzenie uczucia strachu z drżeniem). Dysponując materiałem jeszcze bogatszym, wychodzącym poza obszar języków europejskich, można by pokusić się o bardziej wnikliwe badania i odpowiedzieć na pytanie, które z nazw uczuć są uwarunkowane przede wszystkim fizjologicznie, a które kulturowo. Można przyjąć wstępne założenie, że przy emocjach pierwotnych będzie dominować motywacja fizjologiczna, a przy bardziej złożonych kulturowa. Wymaga to jednak dalszych badań.

\section{Literatura}

Abramowiczówna Z. (red.), 1958-1965, Stownik grecko-polski, t. 1-4, Warszawa. Basaj M., Siatkowski J., 2006, Bohemizmy w języku polskim. Stownik, Warszawa. Boryś W., 2001, Stownik etymologiczny języka polskiego, Kraków.

${ }^{3}$ Dotyczy to na przykład polskich (i ogólnosłowiańskich) leksemów strach i gniew. Oba mają różne objaśnienia. Jeśli chodzi o gniew - najwięcej zwolenników ma ączenie go z czasownikiem niecić (w tym wyrazie miałoby zaniknąć nagłosowe g-) albo też z rzeczownikiem gnój. Po szczegóły odsyłam do słowników etymologicznych, (np. Boryś 2001: 168; Sławski 1952-1978: 304). Strach łączony jest z przymiotnikiem srogi (Boryś 2001: 168), ale także z prasłowiańskim *stradati 'cierpieć' i *strastъ 'cierpienie'; istnieją też inne próby objaśnień. 
Buttler D., 1978, Rozwój semantyczny wyrazów polskich, Warszawa.

Dauzat A., 1954, Dictionnaire étymologique de la langue française avec un supplément lexicologique et un supplément chronologique, Paris.

Devoto G., 1968, Avviamento alla etimologia italiana. Dizionario etimologico, Firenze.

Korpanty J. (red.), 2001-2003, Stownik tacińsko-polski, t. 1-2, Warszawa.

Sławski F., 1952-1978, Słownik etymologiczny języka polskiego, Kraków. 